\title{
Editorial
}

Viktorija Skvarciany*

\section{Editorial to Topical Issue "Business and Management”}

https://doi.org/10.1515/openec-2018-0012

Received December 28, 2018; accepted December 31, 2018

\begin{abstract}
A brief overview on the 10th International Scientific Conference "Business and Management" organised by the Faculty of Business Management of Vilnius Gediminas Technical University (Vilnius, Lithuania) on May 3-4, 2018.
\end{abstract}

Keywords: Economics Engineering, Financial Engineering, Business Technologies, Business Management

The Topical Issue contains the papers that were presented at the 10th International Scientific Conference "Business and Management" that was organised by the Faculty of Business Management of Vilnius Gediminas Technical University (Vilnius, Lithuania) on May 3-4, 2018.

The Conference program included both plenary meetings and works in sessions. The number of registered participants reached 200 guests, and the number of articles submitted was 170 . The plenary meeting included three speeches. Before the plenary meeting started, Prof Dr Jelena Stankeviciene, the Dean of the Faculty of Business Management, welcomed the guests and announced the agenda of the plenary meeting. After welcome speech, Prof Dr Jelena Stankeviciene gave a floor to the first speaker Prof Dr Robert Savickas (George Washington University, USA). He presented his research results on "Economic and corporate growth, technology, goal-based portfolios, and asset pricing”. The presenter talked about the traditional investment theory that described optimal portfolio decisions based on mean-variance optimisation, in which risk-averse agents seek to maximise the return in excess of the risk-free rate and minimise the total volatility of their portfolio return. The second speaker was Dr Povilas Lastauskas (Bank of Lithuania). He delivered a speech on his research on Global Spillover Effects of Volatility Shocks. The study examined policy uncertainty focus on 33 countries representing 90 per cent of all the world's countries. The third speaker was Prof Dr Maurizzio Pompella (University of Siena, Italy). The focus of the Professor's speech was concerned with the relationship between a series of financial reforms and the Global Financial Crisis.

After the plenary meeting the participants continued work in sections which were as follows:

- Contemporary Issues in Economics Engineering

- Financial Engineering

- Social, Legal and Economic Business Environment

- Business Technologies and Sustainable Entrepreneurship

- Contemporary Business Management: Challenges and Opportunities

The accepted articles were published in Conference Proceedings, and the selected papers were published in the Conference partner journals (Journal of Business Economics and Management; Business: Theory and Practice, Business, Management and Education; Open Economics).

The next conference "Business and Management" is scheduled for May 7-8, 2020; hence you all are welcome (http://bm.vgtu.lt).

Article note: This article is a part of Topical Issue “Business and Management” edited by Viktorija Skvarciany.

*Corresponding author: Viktorija Skvarciany, Vilnius Gediminas Technical University, Vilnius, Lithuania, E-mail: viktorija. skvarciany@vgtu.lt 